\title{
PERAN LINGKUNGAN BELAJAR DALAM PEMBENTUKAN KARAKTER PESERTA DIDIK DI LEMBAGA PENDIDIKAN PONDOK PESANTREN SALAFIYAH SYAFI'IYAH SUKOREJO
}

\begin{abstract}
:
Oleh:

St. Shofiyah

Shofwatul Fu'adah

Email:

st.shofiyah90@gmail.com shofwatulfuadah07@gmail.com

Universitas Ibrahimy

Educational institutions are a learning environment that is a planned container that is believed to be able to change or shape children's character to be better than before with all theirpotential. The learning environment should be understood as an important factor in shaping the character of students after the family environtment. The thing that needs to be considered in the success of character education in schools is a conducive-academic environment. The school environment can affect the child's personality, and from the environment, students will learn and shape their character naturally. The result showed the things that affect to character formation in educational institution at Pondok Pesantren Salafiyah Syafi'iyah area conducive learning environment and then in its implementation exemplary models, habituation, and discipline from all parties so that there is a real role model for students how to give examples of real character in life.
\end{abstract}

Keywords: Learning Environment,Character Building, Educational Institution.

\section{PENDAHULUAN}

\section{Konteks Penelitian}

Pendidikan merupakan upaya yang terencana dalam proses pembimbingan dan pembelajaran bagi individu agar tumbuh berkembang menjadi manusia yang mandiri, bertanggung jawab, kreatif, berilmu, sehat, dan berakhlak mulia. Undang-undang Nomor 20 Tahun 2003 tentang Sistem Pendidikan Nasional (Sisdiknas) menegaskan "Pendidikan Nasional berfungsi mengembangkan kemampuan dan membentuk watak serta peradaban bangsa yang bermartabat dalam rangka mencerdaskan kehidupan bangsa, bertujuan untuk berkembangnya potensi peserta didik agar menjadi manusia yang beriman dan bertakwa kepada Tuhan Yang Maha Esa, berakhlak mulia, sehat, berilmu, cakap, kreatif, mandiri, dan menjadi warga negara yang demokratis serta bertanggung jawab.

Dari rumusan tersebut di atas, terlihat bahwa pendidikan nasional mengemban misi yang cukup berat, yakni membangun manusia yang utuh dan paripurna yang memiliki nilai-nilai karakter yang agung, serta memiliki fondasi keimanan dan ketakwaan yang tangguh. Oleh karena itu pendidikan menjadi agent of change yang harus mampu melakukan perbaikan karakter bangsa..

Untuk memiliki nilai-nilai karakter mulia, dibutuhkan sistem pendidikan yang memiliki materi komprehensif (kafah) serta ditopang oleh pengelolaan dan pelaksanaan yang benar. Selain itu juga hal yang sangat berpengaruh dalam pembentukan karakter adalah lingkungan. Baik dalam lingkungan keluarga, sekolah ataupun masyarakat.Jadi, meskipun kehidupan manusia memiliki dasar pembawaan atau bakat, namun faktor lingkungan tidak dapat diabaikan pengaruhnya terhadap perkembangan pribadi manusia umumnya dan anak khususnya, sebagaimana pendapat Sujanto yang menyatakan bahwa "perkembangan pribadi manusia dipengaruhi oleh diri manusia itu sendiri dan lingkungannya."1

\footnotetext{
${ }^{1}$ Agus Sujanto, Psikologi Pendidikan, Jakarta: Aksara Baru, 2015), 66 .
} 
Lembaga pendidikan yang merupakan lingkungan belajar merupakan wadah yang terencana dipercaya dapat merubah atau membentuk karakter anak menjadi lebih baik dari sebelumnya dengan seluruh potensi yang dimiliki. Karakter yang diharapkan dimiliki oleh anak sebagai peserta didik dalam lembaga pendidikan adalah sebagaimana yang diungkapkan dalam buku pelatihan dan pengembangan pendidikan budaya karakter bangsa yang diterbitkan oleh Kementrian pendidikan, ada delapan belas karakter, yaitu religius, jujur, toleran, disiplin, kerka keras, kreatif, mandiri, demokratis, rasa ingin tahu, semangat kebangsaan, cinta tanah air, menghargai prestasi, bersahabat, komunikatif, cinta damai, gemar membaca, peduli lingkungan, peduli sosial, dan tanggung jawab.

Selain sekolah atau madrasah, lingkungan belajar yang sangat tepat untuk membentuk karakter seorang anak adalah pesantren. Pesantren sebagai salah satu lembaga pendidikan, memegang peran yang sangat penting dalam mengembangkan nilai-nilai tersebut. Dengan konsep pendidikannya yang on time "24 jam" pesantren dapat membekali pribadi-pribadi anak didiknya (santri) dengan sikap-sikap rajin, jujur, kreatif, inovatif, bertanggung jawab, bekerja keras serta nilai-nilai terpuji lainnya. Sehingga akhirnya dapat menciptakan insan yang berkepribadian muslim yang tangguh, harmonis, mampu mengatur kehidupan pribadinya, mengatasi masalah-masalah yang timbul, mencukupi kebutuhan serta mengendalikan dan mengarahkan tujuan hidupnya. ${ }^{2}$

Pondok Pesantren Salafiyah Syafi'iyah merupakan salah satu pesantren di pulau Jawa, yang memiliki berbagai macam lembaga pendidikan baik RA, madrasah atau sekolah dari tingkatan terendah sampai perguruan tinggi. ada berbagai macam kegiatan dan cara terbaik untuk membentuk karakter anak, tidak hanya pendidikan agama dan umum saja yang diajarkan tetapi nilai-nilai moral dan etika berprilaku juga. Sehingga bisa dipastikan bahwa pembentukan karakter anak yang belajar di sekolah atau madrasah di bawah naungan pesantren akan lebih baik.

\footnotetext{
${ }^{2}$ Muhammad Ali Ridho, Pendidikan Pesantren Dalam Pembentukan Karakter, (https://www.nu.or.id/post/ $\mathrm{read} / 55939 /$ pendidikan-pesantren-dalam-pembentukankarakter), diakses pada 12 Desember 2019.
}

Di Pondok Pesantren Salafiyah Syafi'iyah ada dua waktu belajar untuk lembaga pendidikan. Madrasah (MI/MTs/MA/MTI) yang notabenenya pembelajaran agama dilaksanakan di pagi hari, yakni pukul 07.00 - 10.00 WIB. Sedangkan Sekolah Umum (SD/SMP/SMA/SMK/PT) dilaksanakan pada siang hari, yakni dari pukul 13.00-17.00 WIB. Dalam setiap lembaga pendidikan mempunyai aturan-aturan tersendiri yang tidak lepas dari aturan pesantren pada umumnya. Tenaga pendidik dan kependidikan yang ada dibawah naungan pesantren pun bisa merangkap mengajar atau bertugas di pagi atau siang hari.

Berdasarkan penelitian awal yang peneliti lakukan pada lembaga pendidikan di bawah naungan Pondok Pesantren Salafiyah Syafi'iyah Sukorejo sebagai salah satu lingkungan belajar anak yakni lembaga madrasah dan sekolah, ada hal yang cukup aneh dan mengganjal. Yakni sikap dan sifat anak atau siswa terhadap guru dan aturan-aturan yang telah ditetapkan oleh lembaga pendidikan tersebut. Walaupun dengan aturan yang sama, naungan yang sama, bahkan tak jarang dengan pengajar yang sama, ada perbedaan yang cukup signifikan.

Ketika anak belajar di Madrasah, ta'dzimnya pada guru sangat tampak dan dapat dirasakan, mereka bisa patuh dan taat pada aturan yang berlaku dari aturan yang sederhana, semisal memakai kaos kaki, datang tepat waktu, tidak membawa makanan ke dalam kelas sebagai bentuk kedisplinan dan lain sebagainya. Sedangkan ketika belajar di sekolah, mereka bisa berubah drastis seakan mempunyai dua karakter yang berbeda. Cara mereka menyapa guru, bergaul dengan teman, cara belajar, serta dalam mematuhi aturan tidak sama baiknya dengan ketika berada di lingkungan madrasah pada pagi hari.

Berdasarkan uraian di atas, maka peneliti tertarik untuk melakukan penelitian tentang peran lingkungan belajar dalam pembentukan karakter peserta didik di lembaga pendidikan Pondok Pesantren Salafiyah Syafi'iyah Sukorejo.

\section{Perumusan Masalah}

1. Bagaimana peran lingkungan belajar beserta faktor-faktornya yang dapat mempengaruhi kepribadian anak di Pondok Pesantren Salafiyah Syafi'iyah Sukorejo? 


\section{Tujuan Penelitian}

1. Menjelaskan secara komprehensif peran lingkungan belajar beserta faktor-faktornya yang dapat mempengaruhi kepribadian anak di Pondok Pesantren Salafiyah Syafi'iyah Sukorejo.

\section{Metode Penelitian}

Penelitian ini menggunakan metode kualitatif dengan jenis fenomenologi. Inti dari fenomenologi adalah studi mendalam untuk mmenggali pengalaman orang secara essensial, baik itu yang menyangkut emosi seseorang, peristiwa yang dialami, benturan budaya dan sebagainya. Peristiwanya bisa pada level individu, kelompok atau masyarakat. ${ }^{3}$ Peneliti berusaha memahami peristiwa-peristiwa dan hal-hal yang berkaitan dengan orang-orang yang peneliti amati yang berada dalam situasi tetentu. Penelitian ini dilakukan di Pondok Pesantren Salafiyah Syafi'iyah Sukorejo Situbondo Jawa Timur.

Dalam mengumpulkan data, teknik yang digunakan dalam penelitian ini adalah observasi, wawancara dan dokumenter. Miles dan Huberman mengemukakan bahwa aktivitas dalam analisis data kualitatif dilakukan secara interaktif dan berlangsung secara terus menerus sampai tuntas, sehingga datanya sudah jenuh. Aktivitas dalam analisis data, yaitu data reduction, data display, dan conclusion drawing/verification. ${ }^{4}$

Analisis data ini dilakukan secara induktif, peneliti terjun kelapangan mempelajari, menganalisis, menafsirkan dan menarik kesimpulan dari fenomena yang ada di lapangan terutama mengenai peran lingkungan belajar dalam pembentukan karakter peserta didik di lembaga pendidikan Pondok Pesantren Salafiyah Syafi'iyah Sukorejo Situbondo Jawa Timur.

\section{KERANGKA KONSEPTUAL}

\section{Pembentukan Karakter}

Dalam agama Islam, pendidikan karakter memiliki kesamaan dengan pendidikan akhlak. Istilah akhlak bahkan sudah masuk ke dalam bahasa Indonesia yaitu akhlak. Akhlak (dalam bahasa Arab: al-Akblaq) berasal dari kata alkhulqu, alkhuluq yang

\footnotetext{
${ }^{3}$ Mudjia Rahardjo, Metodologi Penelitian Kualitatif, ( Malang: Republik Media, 2020), 57.

${ }^{4}$ Sugiyono, Metode Penelitian Kuantitatif Kualitatif dan R\&D, (Bandung: Penerbit Alfabeta, 2011), 24.
}

mempunyai arti watak, tabiat, keberanian dan agama. Haedar Nasir dalam bukunya mengungkapkan bahwa akhlak ialah kemauan yang kuat tentang sesuatu yang dilakukan berulang-ulang sehingga menjadi adat (membudaya) yang mengarah pada kebaikan atau keburukan. ${ }^{5}$

Pembentukan karakter dapat dilakukan dengan berbagai pendekatan dan dapat berupa berbagai kegiatan yang dilakukan secara intra kurikuler maupun ekstrakurikuler. Kegiatan intrakurikuler terintegrasi ke dalam mata pelajaran, sedangkan kegiatan ekstrakurikuler dilakukan di luar jam pelajaran. ${ }^{6}$

Adapun strategi dalam pendidikan karakter dapat dilakukan melalui sikap-sikap sebagai berikut:?

1. Keteladanan

2. Penanaman kedisiplinan

3. Pembiasaan

4. Menciptakan suasana yang kondusif

5. Integrasi dan internalisasi.

Anak memiliki sifat yang paling senang meniru. Orang tuanya merupakan lingkungan terdekat yang selalu mengitarinya dan sekaligus menjadi figur idolanya. Setelah itu ada lingkungan masyarakat juga lingkungan sekolah yang juga membentuk karakternya seiring bertambah usia. Terbentuknya karakter memerlukan proses yang relatif lama dan terus menerus. Oleh karena itu, sejak dini harus ditanamkan pendidikan karakter pada anak. Pembiasaan yang terus menerus akan membentuk karakter. Seperti kalimat yang menyatakan "pertama-tama kita yang membentuk kebiasaan, kemudian kebiasaan yang membentuk kita." Maka pembiasaan yang baik akan membentuk pribadi menjadi lebih baik.

\section{Lingkungan Belajar dalam Pembentukan Karakter}

Lingkungan seharusnya dipahami sebagai faktor penting dalam membentuk karakter para siswa. Pada dasarnya, meskipun kehidupan manusia memiliki dasar pembawaan atau bakat, namun faktor

\footnotetext{
${ }^{5}$ Haedar Nashir, Pendidikan Karakter Berbasis Agama dan Kebudayaan, (Yogyakarta: Multi Presindo, 2013), 23.

${ }^{6}$ M. Furqan Hidayatullah, Pendidikan Karakter: Membangun Peradaban Bangsa, (Surakarta: Yuma Pustaka; 2010), 41.

${ }^{7}$ M. Furqan Hidayatullah, Pendidikan Karakter: Membangun Peradaban Bangsa, (Surakarta: Yuma Pustaka; 2010), 41-42.
} 
lingkungan tidak dapat diabaikan pengaruhnya terhadap perkembangan pribadi manusia umumnya dan anak khususnya, sebagaimana pendapat Sujanto yang menyatakan bahwa perkembangan pribadi manusia dipengaruhi oleh diri manusia itu sendiri dan lingkungannya. ${ }^{8}$ Tanggung jawab pendidikan karakter ada pada semua pihak yang mengitarinya, mulai dari keluarga, sekolah, masyarakat, maupun pemerintah.Bahkan, kurikulum pendidikan didesain sedemikian rupa untuk menciptakan peserta didik yang berkarakter. Hal ini sebagai usaha pemerintah dalam membekali persiapan mental peserta didik dalam menghadapi tantangan zaman yang semakin berkembang. ${ }^{9}$

Lingkungan dapat dikatakan merupakan proses pembudayaan anak dipengaruhi oleh kondisi yang setiap saat dihadapi dan dialami anak. Demikian halnya, menciptakan suasana yang kondusif di sekolah merupakan upaya membangun kultur atau budaya yang memungkinkan untuk membangun karakter terutama berkaitan dengan budaya kerja dan belajar di sekolah. Tentunya bukan hanya budaya akademik yang dibangun tetapi budaya-budaya yang lain, seperti membangun budaya berperilaku yang dilandasi akhlak yang baik. ${ }^{10}$

Hal yang perlu diperhatikan dalam menyukseskan pendidikan karakter di sekolah adalah lingkungan yang kondusif-akademik, baik secara fisik maupun nonfisik. Jika tidak ditunjang oleh lingkungan yang kondusif, upaya pendidikan karakter di sekolah akan seperti membangun 'istana pasir di tepi pantai'. Oleh karena itu, perlu pendekatan yang komprehensif dari sekolah, keluarga, dan masyarakat dalan mengembangkan karakter peserta didik yang kuat, baik, dan postif secara konsisten. ${ }^{11}$

Sekolah yang membudayakan warganya untuk disiplin, aman, bersih, rapi, maka akan mewujudkan terciptanya suasana karakter yang demikian. Terciptanya suasana yang kondusif akan

\footnotetext{
${ }^{8}$ Agus Sujanto, Psikologi Pendidikan, Jakarta: Aksara Baru, 2015), 66.

9 Samsiah Nur, "Urgensi Pendidikan Keuarga dalam pembentukan Embrio Karakter siswa", Kanz el'Imi: Jurnal Studi Islam, Vol.1, No. 1, (Juli: 2016), 80.

${ }^{10}$ M. Furqan Hidayatullah, Pendidikan Karakter: Membangun Peradaban Bangsa, (Surakarta: Yuma Pustaka; 2010), 52.

${ }^{11}$ E. Mulyasa, Manajemen Pendidikan Karakter, (Jakarta: Bumi Aksara, 2011), 19.
}

memberikan iklim yang memungkinkan terbentuknya karakter. Lingkungan sekolah dapat mempengaruhi kepribadian anak, dalam beberapa faktor yang berpengaruh berikut ini $:^{12}$

1. Iklim emosianal kelas: kelas yang iklim emosinya sehat (guru bersikap ramah, dan respek terhadap siswa dan begitu juga berlaku di antara sesama siswa) memberikan dampak yang positif bagi perkembangan psikis anak, seperti merasa nyaman, bahagia mau bekerja sama, termotivasi untuk belajar, dan mau menaati pertauran).

2. Sikap dan perilaku guru: hubungan guru dengan siswa dipengaruhi oleh berbagai faktor di antaranya ialah stereotype yakni budaya terhadap guru (pribadi dan profesi), positif atau negatif. Sikap guru terhadap siswa, metode mengajar, penegakan disiplin dalam kelas dan penyesuaian pribadi guru (personal adjusment of the teacher).

3. Disiplin: ranah pada disiplin ini ialah penegakan tata tertib. Tata tertib ini ditujukan untuk membentuk sikap dan tingkah laku siswa.

4. Prestasi belajar: perolehan prestasi belajar dapat mempengarubi peningkatan harga diri, dan sikap percaya diri siswa.

5. Penerimaan teman sebaya: siswa yang diterima oleh teman-temannya, dia akan mengembangkan sikap postif terhadap dirinya, dan juga orang lain. Dia merasa menjadi orang yang berharga.

Lingkungan yang kondusif harus ditunjang oleh berbagai fasilitas belajar yang menyenangkan; seperti sarana, laboratorium, pengaturan lingkungan, penampilan dan sikap guru, hubungan yang harmonis antara peserta didik dengan guru dan di antara para peserta didik itu sendiri, serta penataan organisasi dan bahan pembelajaran secara tepat, sesuai dengan kemampuan dan perkembangan peserta didik. ${ }^{13}$

\section{Lembaga Pendidikan Pondok Pesantren Salafiyah Syafi'iyah Sukorejo Situbondo.}

Pendidikan Islam yang berorientasi pada pembentukan karakter dapat dilakukan melalui

\footnotetext{
${ }^{12}$ Syamsu Yusuf LN dan Achmad Juntika Nurihsan, Teori Kepribadian, (Bandung: Remaja Rosdakarya, 2011), 31-33.

${ }^{13}$ E. Mulyasa, Manajemen Pendidikan Karakter, (Jakarta: Bumi Aksara, 2011), 20.
} 
banyak model, seperti model pesantren. Pesantren maupun pondok pesantren merupakan lembaga pendidikan Islam yang telah lama mengakar dalam kehidupan masyarakat Indonesia berabad-abad lamanya. Pesantren yang diselenggarakan dalam kehidupan umat Islam berbagai jenis dan coraknya, baik model lama (tradisional) maupun baru (modern) dari berbagai organisasi Islam yang tersebar di Indonesia. ${ }^{14}$

Di Pondok Pesantren Salafiyah Syafi'iyah ini terdapat dua model pendidikan, yakni madrasah dan sekolah umum.Sistem pendidikan madrasah menekankan keseimbangan antara nilai nilai keagamaan atau bisa dikatakan pendidikan karakter lebih intensif berbasis nilai-nilai agama sehingga melahirkan sosok manusia yang shaleh secara kepribadian tetapi berpikiran dan bersikap maju dalam memandang kehidupan. Dalam model madrasah ini, pendidikan karakter dapat dilakukan sepanjang hari di bawah asuhan yang intensif. Pendidikan madrasah (MI/MTs/MA/MTI) dilaksanakan pada pagi hari sejak pukul 07.00 - 10.00 WIB. Sedangkan sekolah umum (SD/SMP/SMA/SMK/PT) dilaksanakan pada sore hari yakni sejak pukul 13.00-17.00 WIB.

Setiap santri mayoritas dari mereka merangkap madrasah dan sekolah. Karena madrasah merupakan program wajib dari pesantren. Sedangkan sekolah umum bisa dibilang sekolah yang disunnahkan. Namun dalam perjalannannya para santri tetap mengikuti sekolah umum di sore hari agar tidak ketinggalan pengetahuan tentang ilmu-ilmu umum serta juga tidak memungkiri untuk kebutuhan masa depan mereka yang membutuhkan ijazah sekolah umum.

Pendidikan karakter dengan model pesantren, madrasah dan sekolah sebenarnya tidak hanya bertumpu pada penyelenggaraan kurikulum formal, tetapi di dalamnya sama pentingnya membangun budaya pesantren, budaya madrasah, dan budaya sekolah yang memberikan proses pembelajaran yang intensif, interaktif, dan berkelanjutan sehingga terbentuk pribadi-pribadi yang bekarakter akhlak mulia. $^{15}$

\footnotetext{
${ }^{14}$ Haedar Nashir, Pendidikan Karakter Berbasis Agama dan Kebudayaan, (Yogyakarta: Multi Presindo, 2013), 27.

${ }^{15}$ Haedar Nashir, Pendidikan Karakter Berbasis Agama dan Kebudayaan, (Yogyakarta: Multi Presindo, 2013), 28.
}

Dalam pelaksanaanya, apakah karakter atau tingkah laku peserta didik menunjukkan hal yang sama antara siswa yang berada di madrasah atau sekolah umum? Pada perjalanannya ada perbedaan yang dirasakan antara karakter atau perilaku siswa ketika mereka sedang berada di madrasah dan ketika bersekolah di sore hari (sekolah umum)dengan muridmurid yang sama walaupun sama-sama berada di dalam lembaga pondok pesantren, hal ini didapatkan dari observasi dan wawancara yang dilakukan pada beberapa guru dan siswi yang bersekolah merangkap madrasah dan sekolah umum.

Hal yang paling terlihat dan dirasakan salah satunya adalah sikap dan perilaku anak atau siswa terhadap guru dan aturan-aturan yang telah ditetapkan oleh lembaga pendidikan tersebut. Walaupun dengan aturan yang sama, naungan yang sama, bahkan tidak jarang dengan pengajar yang sama, ada perbedaan yang cukup signifikan.

Berdasarkan hasil wawancara bersama guru yang mengajar di sekolah dan madrasah ditemukan bahwa ketika anak belajar di madrasah, ta'dzimnya pada guru sangat tampak dan dapat dirasakan, mereka bisa patuh dan taat pada aturan yang berlaku dari aturan yang sederhana, semisal memakai kaos kaki, datang tepat waktu, tidak membawa makanan ke dalam kelas sebagai bentuk kedisiplinan dan lain sebagainya. Sedangkan ketika belajar di sekolah, mereka bisa berubah drastis seakan mempunyai dua karakter yang berbeda. Cara mereka menyapa guru, bergaul dengan teman, cara belajar, serta dalam mematuhi aturan tidak sama baiknya dengan ketika berada di lingkungan Madrasah pada pagi hari. Begitu pula dalam hal kebersihan, para siswa lebih santai dan terkesan kurang memiliki kesadaran untuk terus menjaga kebersihan seperti kelas yang terkadang masih kotor bahkan disaat akan dimulai kegiatan pembelajaran ketika sekolah disore hari (sekolah umum).

Dengan adanya fenomena yang demikian, maka dipastikan ada hal-hal atau faktor yang mempengaruhinya. Sebagaimana yang diungkapkan oleh salah satu siswi Madrasah Tsanawiyah merangkap SMA di sore hari. Ia mengatakan bahwa ketika ia dan teman-temannya bersekolah di sore hari (sekolah umum) mereka merasa lebih bebas. Berbeda dengan ketika berada di madrasah, gurunya lebih serius dan 
selain mengajar, guru memiliki lebih banyak peran seperti mengontrol kebersihan sebelum pembelajaran dimulai, mengingatkan dan mengawasi agar tidak terlambat masuk kelas, dan juga memeriksa para siswi yang tidak memakai kaos kaki. Di sini figur guru dalam memberikan teladan sangat amat dirasakan oleh para siswi.

Hal ini membuat mereka lebih berhatihati dan lebih mentaati peraturan, seperti tidak terlambat masuk kelas, memakai kaos kaki, dan selalu menjaga kebersihan sehingga kebiasaan-kebiasaan ini membentuk suatu karakter/ akhlak yang baik. Sebagaimana diungkapkan oleh Abdullah bin Izz bahwa akhlak adalah suatu keadaan bagi jiwa yang mendorong ia melakukan tindakan-tindakan dari keadaan itu tanpa melalui pikiran dan pertimbangan. Keadaan ini terbagi dua, ada yang berasal dari tabiat aslinya, ada pula yang diperoleh dari kebiasaan yang berulang-ulang. Boleh jadi, pada mulanya tindakan itu melalui pikiran, peringatan dan pertimbangan, kemudian dilakukan terus menerus, maka jadilah suatu bakat dan akhlak. ${ }^{16}$

Para siswi yang berada di madrasah mengungkapkan bahwa para ustadzah atau guru di madrasah utamanya yang menjadi wali kelas selalu mengontrol dan mengikuti pembacaan do'a dan pembacaan nadzam ${ }^{17}$ serta lebih intens dalam memantau dan mendampingi para siswi hingga mereka benar-benar siap memulai pembelajaran bersama para guru dalam mata pelajaran yang bersangkutan pada hari itu. Hal ini berbeda dengan para guru di sekolah umum yang tidak se-intens itu memantau para siswi. Selanjutnya, mereka menambahkan bahwa pembawaan guru yang mengajar di madrasah atau yang biasa disebut ustadzah yang mengajar ilmu agama baik figh, akhlaq, tauhid, Alquran dan sebagainya membangun mindset para siswi bahwa beliau-beliau memiliki pembawaan yang serius dan berwibawa, sehingga membuat para siswi lebih ta'dzim dan sungkan untuk bercanda ria atau sungkan untuk lebih bebas berdiskusi dengan guru kecuali seputar mata pelajaran dan kerohanian.

\footnotetext{
${ }^{16}$ Pupuh Fathurrohman, Dkk., Pengembangan Pendidikan Karakter (Bandung: Refika Aditama, 2013), 65.

${ }^{17}$ Nadzam adalah kalam yang berwazan dan bersajak. Pembacaan nadzam di pondok ini bervariasi sesuai dengan tingkatan madrasahnya, seperti Nadzam Alfyah ibn Malik untuk Madrasah Tsanawiyah dan Madrasah Aliyah.
}

Berbeda dengan guru pada sekolah umum yang cenderung lebih santai dan bisa sharing tentang hal apa pun.

Menurut guru kelas yang memiliki tugas sehari-hari di madrasah menjelaskan bahwa suasana dan lingkungan belajar madrasah di pagi hari dirasa jauh lebih efektif dari pada sekolah umum di sore hari. Di mana para peserta didik masih fresh dan semangat untuk belajar, kondisi ini menambah semangat mereka untuk lebih cepat bergegas berangkat untuk belajar sehingga bisa hadir tepat waktu dan tidak terlambat tiba di madrasah. Sedangkan sekolah disore hari dalam keadaan fisik yang mulai lelah dan kondisi cuaca yang panas sedikit banyak juga berdampak pada kegiatan belajar mereka sehingga dirasa kurang serius dan mendorong mereka untuk lebih santai.

Selain hal-hal yang tersebut di atas, teman dalam belajar juga mempengaruhi karakter atau pembawaan mereka (para siswi) berbeda ketika mereka berada di lingkungan madrasah dan sekolah. Teman-teman sekelas di madrasah baik madrasah tsanawiyah, aliyah, maupun diniyah mayoritas dari mereka tidak sepantaran dalam segi umur. Karena kualifikasi mereka atau tes masuk madrasah ditentukan dari kemampuan membaca kitab kuning bukan dari umur, sehingga para siswi dalam kelas tersebut terdiri dari berbagai usia. Sehingga menurut siswi, hal tersebut menciptakan adanya rasa sungkan di antara mereka, sikap saling menghargai dan juga jarang berbicara yang tidak penting. Hal ini jauh berbeda dengan lingkungan kelas di sekolah umum (baik SDSMK) yang notabene mereka ada dalam frekuensi yang sama, baik dari usia dan keilmuannya, sehingga membuat mereka lebih santai dalam berinteraksi, berkomunikasi bahkan bersenda gurau.

Apapun rumusannya, bahwa masing-masing lembaga pendidikan memiliki ciri khas, terkait perilaku yang dihasilkan. Sekalipun sama-sama sekolah tingkat dasar umum atau sama-sama madrasah, masingmasing lulusannya juga memiliki karakter yang khas. ${ }^{18}$ Lagi-lagi mindset juga sangat berperan dalam pembentukan karakter. Di lingkungan madrasah para siswi berperilaku ta'dzim, taat pada guru/ustadzah, selalu berharap memperoleh berkah dan sejenisnya,

\footnotetext{
${ }^{18}$ Imam Suprayogo, Pengembangan Pendidikan Karakter, Malang: UIN-Maliki Press, 2013), 42.
} 
orientasi seperti itu, membentuk perilaku yang khas. Berbeda dengan itu, tujuan para murid di sekolah umum adalah mendapatkan status lulus dengan nilai unggul. Oleh karena itu, sehari-hari yang dilakukan adalah belajar, menghafalkan ruusrumus, mengerjakan soal dan sejenisnya. Tentang bagaimana perilaku ideal yang harus ditampilkan tidak terlalu menjadi perhatian. ${ }^{19}$

\section{PEMBAHASAN}

Deskripsi mengenai hal hal dalam proses pembentukan karakter peserta didik baik dari hasil observasi dan wawancara yang telah dilakukan, menunjukkan bahwasanya akhlak bersumber dari dalam diri anak dan juga berasal dari lingkungannya. Sebagaimana diungkapkan oleh Ibnu Qudamah yang dijelaskan oleh Fathurrohmahman dalam bukunya bahwa manusia memiliki dua macam karakter, pertama, yang tabi'i, dan kedua ialah karakter yang lain dan diperoleh melalui kebiasaan dan latihan. ${ }^{20}$

Secara konseptual, pendidikan Islam dianggap komprehensif dan sangat ideal, sehingga jika dilaksanakan akan berhasil mengantarkan seseorang menjadi lebih sempurna. Pendidikan Islam akan mampu mengantarkan seseorang mengenal ke-Maha Esa-an Tuhan, para utusan-Nya, kitab suci-Nya, amal saleh dan akhlak karimah. Produk pendidikan seperti ini, akan unggul dibanding dengan pendidikan lainnya. Akan tetapi, pada kenyataannya belum demikian. ${ }^{21}$

Betapa besarnya peran lingkungan dalam membentuk perilaku seseorang yang dapat dilihat dalam gambaran berikut. Bahwa seseorang akan merasa harus berhati-hati tatkala berada di tempat yang terawat, rapi dan bersih. Orang akan ikut menata dirinya agar tidak disalahkan oleh orang lain ketika periakunya tidak sesuai dengan tuntutan lingkungannya. Orang juga akan beradaptasi dengan lingkungan di mana mereka berada. Lingkungan yang rapi, tertib, aman, dan bersih akan memaksa siapa pun bertingkah laku sebagaimana tempat di mana mereka berada. Dari lingkungan, para murid atau anak didik akan belajar dan membentuk karakter

\footnotetext{
${ }^{19}$ Imam Suprayogo, Pengembangan Pendidikan Karakter, (Malang: UIN-Maliki Press, 2013), 42.

${ }^{20}$ Pupuh Fathurrohman, Dkk., Pengembangan Pendidikan Karakter (Bandung: Refika Aditama, 2013), 68.

${ }^{21}$ Imam Suprayogo, Pengembangan Pendidikan Karakter, (Malang: UIN-Maliki Press, 2013), 29.
}

mereka secara alamiah. Lingkungan pendidikan harus dipandang sebagai bagian penting dalam membentuk pribadi anak-anak.

\section{Peran Lingkungan Belajar dan Faktor-Faktor yang Mempengaruhi Kepribadian Anak}

\section{Pembiasaan}

Akhlak dapat dipelajari dan diinternalisasikan dalam diri seseorang melalui pendidikan. Di antaranya dengan metode pembiasaan. Dengan adanya kemungkinan diinternalisasikan nilai nilai akhlak ke diri anak (jiwa) seseorang, memungkinkan pendidik melakukan pembinaan akhlak. ${ }^{22}$ Pembiasaan yang dilakukan sejak dini akan membawa kegemaran dan kebiasaan tersebut menjadi semacam adat kebiasaan sehingga menjadi bagian tidak terpisahkan dari kepribadiannya.

Dalam konteks pendidikan karakter, peran guru sangat vital sebagai sosok yang diidolakan, serta menjadi sumber inspirasi dan motivasi muiridmuridnya. Sikap dan perilaku seorang guru sangat membekas dalam diri seorang murid, sehingga ucapan, karakter, dan kepribadian guru menjadi cermin murid. 23

Di madrasah pondok putri Pesantren Salafiyah Syafi'iyah ini, para siswi memiliki kebiasaan-kebiasaan yang baik, tertib, selalu menjaga kebersihan, rapi dengan menggunakan kaos kaki dan menggunakan inner jilbab. Tidak lain karena pembiasaan-pembiasaan yang dilakukan oleh guru atau ustadzah. Karena selain mengajar, para ustadzah utamanya juga yang merangkap sebagai wali kelas selalu mendampingi para siswi dalam menjaga kebersihan, membaca doa dan nadzam dan lainnya. Inilah yang kemudian membentuk karakter dan kepribadian para murid.

\section{Keteladanan}

Hal yang perlu disentuh terlebih dahulu untuk mengembangkan pendidikan karakter atau akhlak yang mulia adalah para guru atau pendidiknya. Maka jika mengikuti apa yang dilakukan oleh nabi, maka harus terlebih dahulu membangun karakter para guru-gurunya itu sendiri. Para murid, selanjutnya akan

\footnotetext{
${ }^{22}$ Pupuh Fathurrohman, Dkk., Pengembangan Pendidikan Karakter (Bandung: Refika Aditama, 2013), 66.

${ }^{23}$ Jamal Ma'mur Asmani, Buku Panduan Internalisasi Pendidikan Karakter di Sekolah, (Jogjakarta: Diva Press, 2011), 72.
} 
meniru dengan sendirinya. ${ }^{24}$ Anak didik adalah orang yang tengah memerlukan pengetahuan, bimbingan dan pengarahan. Keteladanan menjadi salah satu hal klasik bagi berhasilnya sebuah pendidikan karakter.

Keteladanan mempunyai arti penting dalam mendidik kepribadian anak, hal ini menjadi titik sentral dalam mendidik dan membina kepribadian anak didik, kalau pendidik berkepribadian baik, ada kemungkinan anak didiknya juga berkepribadian baik, karena murid meniru gurunya. ${ }^{25}$ Dengan demikian keteladanan menjadi penting dalam pendidikan kepribadian, keteladanan akan menjadi metode ampuh dalam membina kepribadian anak.

Tumpuan pendidikan karakter ada pundak guru, konsistensi dalam mengajarkan pendidikan karakter tidak sekedar melalui sesuatu yang dikatakan melalui pembelajaran di kelas, melainkan nilai itu juga tampil dalam diri sang guru, dalam kehidupannya yang nyata di luar kelas. Karakter guru (meskipun tidak selalu) menentukan warna kepribadian anak didik. ${ }^{26}$ Keteladanan dan kecintaan yang kita pancarkan kepada anak, serta modal kedekatan yang dibina akan membawa mereka mempercayai pada kebenaran perilaku, sikap dan tindakan kita. ${ }^{27} \mathrm{Hal}$ inilah yang kemudian akan memudahkan untuk membawa murid pada kebaikan-kebaikan.

Inilah yang dirasakan oleh para siswi di madrasah. Salah satu alasan perilaku mereka berbeda ketika di madrasah dan sekolah adalah keteladanan guru atau ustadzah di madrasah sangat mempengaruhi karakter mereka sehingga rasa ta'dzৃim begitu tinggi, dan nilai-nilai keteladanan guru telah terinternalisasi dengan baik pada kebiasaan dan karakter mereka. Karena para murid dengan sendirinya meniru perilaku sang guru.

\section{Kedisiplinan}

Karakter dikembangkan melalui tahap pengetahuan (knowing), pelaksanaan (acting),

\footnotetext{
${ }^{24}$ Imam Suprayogo, Pengembangan Pendidikan Karakter, (Malang: UIN-Maliki Press, 2013), 40.

${ }^{25}$ Pupuh Fathurrohman, Dkk., Pengembangan Pendidikan Karakter (Bandung: Refika Aditama, 2013), 56.

${ }^{26}$ Jamal Ma'mur Asmani, Buku Panduan Internalisasi Pendidikan Karakter di Sekolah, (Jogjakarta: Diva Press, 2011), 68

${ }^{27}$ Abdul Majid, Pendidikan Karakter Perspektif Islam, (Bandung: Remaja Rosdakarya, 2013), 117.
}

dan kebiasaan (babit). Karakter tidak terbatas pada pengetahuan saja.Sesorang yang memiliki pengetahuan tentang kebaikan belum tentu mampu bertindak sesuai dengan yang diketahuinya, jika tidak terlatih (menjadi kebiasaan) untuk melakukan kebiasaan tersebut. ${ }^{28}$ Dalam hal pelaksanaan (knowing), para murid membutuhkan kedisiplinan.

Kedisiplinan menjadi alat yang ampuh dalam mendidik karakter. Disiplin pada hakikatnya adalah suatu ketaatan yang sungguh-sungguh yang didukung oleh kesadaran untuk menunaikan tugas kewajiban serta berperilaku sebagaimana mestinya menurut aturan-aturan atau tata kelakuan yang seharusnya berlaku di dalam suatu lingkungan tertentu. ${ }^{29}$

Pembiasaan-pembiasaan yang dilakukan untuk mengikuti peraturan dan tata tertib yang berlaku serta keteladanan-keteladanan yang dilakukan oleh para guru atau ustadzah di madrasah yang ada di Pondok Putri Pesantren Salafiyah Syafi'iyah ini membentuk karkater disiplin pada para siswi. Karena penerapan aturan yang dilaksanakan dan dicontohkan oleh para guru menciptakan suatu penegakan kedisiplinan. Pada dasarnya, penegakan disiplin adalah mendidik seseorang taat pada aturan dan tidak melanggar larangan yang dilandasi oleh sebuah kesadaran.

\section{Lingkungan yang Kondusif}

Menciptakan suasana yang kondusif di lingkungan belajar merupakan upaya membangun kultur atau budaya yang memungkinkan untuk membangun karakter terutama berkaitan dengan budaya kerja dan belajar di sekolah. Tentunya bukan hanya membangun budaya akademik tetapi juga budaya-budaya yang lain, seperti membangun budaya berperilaku yang dilandasi akhlak yang baik. ${ }^{30}$

Lingkungan belajar di madrasah putri Pondok Pesantren Salafiyah Syafi'iyah ini berhasil bukan hanya dalam membangun suasana belajar yang kondusif, namun juga menciptakan karakterkarakter utama yang baik tanggung jawab, disiplin,

\footnotetext{
${ }^{28}$ Jamal Ma'mur Asmani, Buku Panduan Internalisasi Pendidikan Karakter di Sekolah, (Jogjakarta: Diva Press, 2011), 86.

${ }^{29}$ M. Furqan Hidayatullah, Pendidikan Karakter: Membangun Peradaban Bangsa, (Surakarta: Yuma Pustaka; 2010), 45.

${ }^{30}$ M. Furqan Hidayatullah, Pendidikan Karakter: Membangun Peradaban Bangsa, (Surakarta: Yuma Pustaka; 2010), 52.
} 
taat aturan, berkomunikasi yang baik, berperilaku sopan dan ta'dzim, kasih sayang, saling menghargai, serta sifat-sifat utama lainnya melalui proses yang bersifat edukatif, partisipatif, dan dapat diteladani secara nyata dari para guru atau ustadzah.

Waktu belajar di madrasah yang dilaksanakan di pagi hari juga menjadi faktor pendukung terlaksananya pembelajaran yang kondusif di pondok pesantren ini, serta sifat saling menerima antar teman sekelas yang tidak sebaya dalam umur namun sebaya dari segi pengetahuan atau keilmuannya dalam memahami kitab kuning juga telah berhasil mengembangkan sikap positif dan memunculkan sikap saling menghargai di antara para pererta didik.

\section{SIMPULAN}

Pengembangan dan pembentukan pendidikan karakter di lembaga pendidikan tidak hanya melalui proses pembelajaran. Sama halnya juga di lembaga Pondok Pesantren Salafiyah Syafi'iyah putri khususnya karakter-karakter utama yang baik yang berhasil diciptakan oleh lembaga madrasah yang ada di pesantren ini. Hal ini yangkemudian membedakan atau memunculkan perbedaan karakter dan perilaku para siswi ketika mereka ada di madrasah dan ketika berada di sekolah. Berikut ini adalah faktor-faktor yang mempengaruhi pembentukan karakter peseta didik, diantaranya lingkungan belajar yang kondusifdan kemudian dalam pelaksanaannya dicontohkan model keteladanan, pembiasaan, kedisiplinan dari seluruh pihak sehingga ada role model (model acuan) yang nyata bagi peserta didik bagaimana contoh berkarakter yang nyata dalam kehidupan. Terdapat keteladanan bagaimana hidup benar, baik, jujur, tanggung jawab, disiplin, taat aturan, berkomunikasi yang baik, berperilaku sopan dan ta'drim, kasih sayang, saling menghargai, serta sifat-sifat utama lainnya melalui proses yang bersifat edukatif, partisipatif, dan dapat diteladani secara nyata. Hingga para murid melihat aksi nyata dari sebuah karakter bukan hanya bicara dan arahan atau memerintah saja.

\section{DAFTAR RUJUKAN}

Asmani, Jamal Ma'mur. Buku Panduan Internalisasi Pendidikan Karakter di Sekolah. Jogjakarta: Diva Press, 2011.

Fathurrohman, Pupuh, Dkk., Pengembangan Pendidikan Karakter. Bandung: Refika Aditama, 2013.

Hidayatullah, M. Furqan. Pendidikan Karakter: Membangun Peradaban Bangsa. Surakarta: Yuma Pustaka; 2010.

Majid, Abdul. Pendidikan Karakter Perspektif Islam. Bandung: Remaja Rosdakarya, 2013.

Mulyasa, E. Manajemen Pendidikan Karakter. Jakarta: Bumi Aksara, 2011.

Nashir, Haedar. Pendidikan Karakter Berbasis Agama dan Kebudayaan. Yogyakarta: Multi Presindo, 2013.

Nur, Samsiah. «Urgensi Pendidikan Keuarga dalam pembentukan Embrio Karakter siswa“, Kan₹ el'Imi: Jurnal Studi Islam, Vol.1, No. 1, (Juli: 2016), 80.

Rahardjo, Mudjia. Metodologi Penelitian Kualitatif. Malang: Republik Media, 2020.

Sugiyono. Metode Penelitian Kuantitatif Kualitatif dan R\&OD. Bandung: Penerbit Alfabeta, 2011.

Sujanto, Agus. Psikologi Pendidikan. Jakarta: Aksara Baru, 2015.

Suprayogo, Imam. Pengembangan Pendidikan Karakter. Malang: UIN-Maliki Press, 2013.

Syamsu Yusuf LN dan Achmad Juntika Nurihsan, Teori Kepribadian. Bandung: Remaja Rosdakarya, 2011.

Muhammad Ali Ridho, Pendidikan Pesantren Dalam Pembentukan Karakter, (https://www.nu.or. $\mathrm{id} /$ post/read/55939/pendidikan-pesantrendalam-pembentukan-karakter), diakses pada 12 Desember 2019. 